\section{The fightback starts here}

W ill 2003 be seen as a turning point in the battle against the infectious diseases - such as malaria, tuberculosis (TB) and AIDS - that blight the lives of millions of people across the developing world? Certainly, big sums of money have now started to flow, and research and control efforts have begun to come together.

This was the year in which US President George Bush pledged to spend \$15 billion over five years to tackle AIDS in Africa and the Caribbean. The Global Fund to Fight AIDS, Tuberculosis and Malaria, backed by donations from the world's wealthy nations, approved projects worth $\$ 623$ million in 50 countries, bringing its total spend to almost $\$ 3$ billion. And the philanthropic Bill \& Melinda Gates Foundation gave out $\$ 700$ million for global health — including $\$ 200$ million for basic research.

Although most of the new funds are for efforts to control disease, they will have knock-on effects for research, argues Richard Feachem, executive director of the Global Fund. "They represent a major increase in demand, and guaranteed demand at high volumes is what fuels R\&D," he says. "The world will know that there is now a buyer for medicines for diseases of poverty." Control funds also pay directly for epidemiological and clinical research, providing substantial new data, particularly on drug resistance, Feachem adds.

AIDS has cruelly exposed the problem of restricted access to expensive drugs in poor countries. But at least new drugs exist for AIDS. For malaria, TB and a host of other diseases, there has been no significant new therapy for decades, because the marketdriven drug industry has had little incentive to develop them.

But there are now signs of a new model for drug development for such diseases, in which the public sector works in tandem with the pharmaceutical industry. The Swiss-based multinational Novartis, for instance, has teamed up with the government of Singapore to launch the Novartis Institute of Tropical Diseases, which will focus initially on dengue fever and multidrug-resistant TB. Novartis will provide most of the institute's annual budget of some $\$ 15$ million, and will make any drugs it finds available to developing countries without royalties. The centre hopes to punch above its weight by getting governments and philanthropists to pay for the most expensive aspects of drug development, such as clinical trials.

A similar public-private partnership underpins the Drugs for Neglected Diseases Initiative, launched in July, which will seek cures for sleeping sickness, Chagas' disease

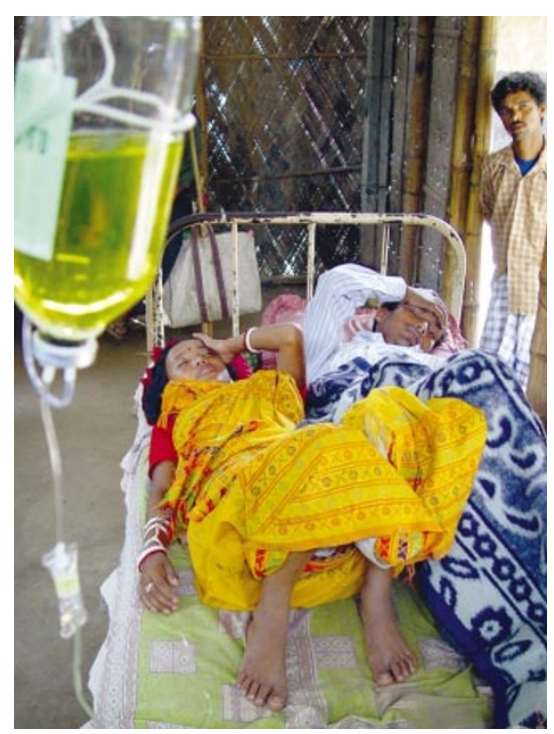

Help at hand: malaria sufferers have been given hope by several well-funded disease initiatives.

and leishmaniasis. These efforts join existing partnerships such as the Medicines for Malaria Venture (MMV), the Malaria Vaccine Initiative and the Global Alliance for TB Drug Development. It is too soon to say whether these initiatives will deliver, as their research leads have yet to survive the long trek to the clinic. But all have strong product pipelines, where little or nothing existed previously.

The Gates foundation has spurred the growth of such partnerships, priming them with millions of dollars. In September, it gave the MMV an extra $\$ 40$ million to bring to the clinic the four most-advanced drugs in its 21-candidate pipeline.

Even the wildest optimists, however, point out that the money now being spent is a fraction of the sum needed to defeat AIDS, malaria, TB and other devastating diseases. Indeed, it is likely to be decades before we can assess the impact of today's investments in research and control. "They will need to be sustained for more than a generation to make any significant impact," warns Paul Herrling, head of corporate research with Novartis. Declan Butler

Global Fund to Fight AIDS, Tuberculosis and Malaria

\section{www.theglobalfund.org}

Bill \& Melinda Gates Foundation

www.gatesfoundation.org

Drugs for Neglected Diseases Initiative

www.dndi.org

Medicines for Malaria Venture

www.mmv.org

Malaria Vaccine Initiative

www.malariavaccine.org

Global Alliance for TB Drug Development

www.tballiance.org
NASA

Trawling through the wreckage

orror greeted the firework display that lit up the skies above Texas on 1 February. When the space shuttle Columbia disintegrated on its return to Earth, it shocked everyone - even the handful of NASA engineers who had worried whether the craft might have been seriously damaged by an errant piece of foam on take-off. But in hindsight, disaster seemed inevitable. Seven months later, the accident investigation board detailed how complacent NASA had become about the risks of shuttle flight, and how the space agency had long been trying to accomplish too much with too few resources.

The mood was very different from the 'let's-get-back-on-the-horse' reaction to Challenger's loss in 1986. There were no calls to build a replica replacement vehicle. Instead, the investigation board advised NASA to come up with an alternative craft fast, and to phase out the entire shuttle fleet as soon as possible - a decision the agency had been circling for years. Now NASA and its overseers in Congress and the White House are left struggling with how, or even whether, astronaut flights should continue.

The board also called for a national debate on the subject of manned spaceflight. So far, all that has come of this is a series of congressional hearings, with Sherwood Boehlert (Republican, New York), who chairs the House of Representatives' Committee on Science, taking the lead. Boehlert has argued that it is difficult to determine how NASA should proceed until it can be determined what, exactly, its priorities are: should NASA emphasize science, or manned missions of exploration? While confusion reigns, Boehlert helped put a halt to the agency's plan to build a new Orbital Space Plane until it can decide exactly what the vehicle will be used for - other than to serve as a lifeboat for the International Space Station.

As for the space station itself, this was the year in which research on the orbiting laboratory was supposed to be ramped up. Instead, those plans were put on hold, as NASA was forced by the absence of shuttle flights to scale back to a two-astronaut maintenance crew.

The best news for NASA from 2003 is that the year is almost over. The next year looks set to be one of scientific discovery, with a mission to retrieve a sample from a comet, two Mars rovers scheduled to reach their destinations in January, and Cassini due to arrive at Saturn in July. Press reports have 


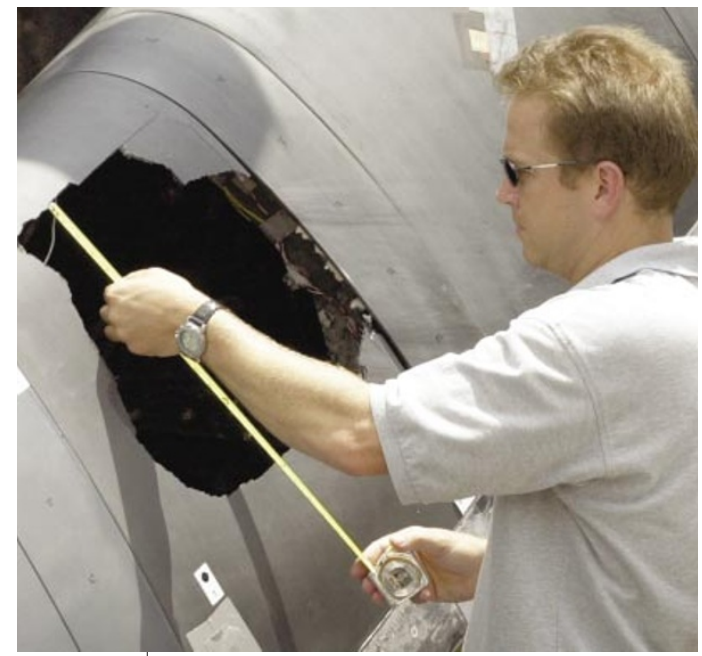

This NASA test shows that insulating foam could have punched a similar hole in Columbia's wing.

also suggested that the White House will unveil a new space initiative - possibly a return to the Moon - within the next few months. Certainly, the agency needs to find itself a convincing new vision, and fast.

Tony Reichhardt

\section{Membrane proteins}

\section{Channel voyager makes waves}

They are the gatekeepers of the cell, responsible for the movement of ions across its outer membrane. And 2003 was the year in which the scientist who painstakingly deciphered many of their structures received the ultimate honour for his work - just months after his latest data challenged orthodox views in the field.

Beginning with a landmark paper ${ }^{1}$ published in 1998, Rod MacKinnon of Rockefeller University in New York has determined the detailed structures of several important ion channels in the cell membrane $e^{2-6}$. Many of his colleagues thought he was embarking on a fool's errand, as proteins embedded in lipid membranes are notoriously difficult to crystallize for X-ray structural analysis. The magnitude of his achievement helps to explain why he was awarded a share of this year's Nobel Prize in Chemistry - a remarkably rapid response from the usually conservative awarding committee.

Indeed, ion channels have not yet yielded all of their secrets, and it was in investigating a remaining mystery that MacKinnon this year ignited a heated debate. Among the most important ion channels, involved in regulating neural impulses, are potassium channels that can be switched on and off according to the voltage across a cell's membrane. In May, MacKinnon's group published the first crystal structure of one of these 'voltage-gated' potassium channels ${ }^{7,8}$. "It's a major breakthrough," comments electrophysiologist Chris Miller of Brandeis University in Waltham, Massachusetts, one of MacKinnon's early mentors.

In the absence of a detailed structure, researchers interested in such channels had used electrophysiological and molecular data to develop a mechanism for voltage gating. Voltage-gated potassium channels were known to consist of four identical protein subunits around a central core, and most researchers had assumed that the voltagesensitive domains would be situated in the heart of each subunit. They were thought to undergo delicate, screw-like movements in response to changes in voltage, allowing potassium ions to rush through.

In contrast, MacKinnon's structure places the voltage sensors on the exterior of each subunit, extending into the cell membrane. According to his suggested mechanism, the sensors open the channel by heaving through the membrane in large, paddle-like strokes - more like weightlifting than the molecular ballet envisaged earlier.

Critics claim that MacKinnon's mechanism is unrealistic. "Previous and continuing experimental studies suggest that the paddle model will not hold up," says electrophysiologist Richard Horn of Jefferson Medical College in Philadelphia.

But MacKinnon is undaunted. "I think that these new ideas, which are based on very solid structural and functional data, are correct," he asserts.

\section{Alison Abbott}

$$
\begin{aligned}
& \text { 1. Doyle, D. A. et al. Science 280, 69-77 (1998). } \\
& \text { 2. Zhou, M., Morais-Cabral, J. H., Mann, S. \& MacKinnon, R. } \\
& \text { Nature 411, 657-661 (2001). } \\
& \text { 3. Morais-Cabral, J. H., Zhou, Y. \& MacKinnon, R. Nature 414, } \\
& \text { 37-42 (2001). } \\
& \text { 4. Zhou, Y., Morais-Cabral, J. H., Kaufman, A. \& MacKinnon, R. } \\
& \text { Nature 414, } 43-48 \text { (2001). } \\
& \text { 5. Dutzler, R., Campbell, E. B., Cadene, M., Chait, B. T. \& } \\
& \text { MacKinnon, R. Nature 415, 287-294 (2002). } \\
& \text { 6. Jiang, Y. et al. Nature 417, 515-522 (2002). } \\
& \text { 7. Jiang, Y. et al. Nature 423, 33-41 (2003). } \\
& \text { 8. Jiang, Y., Ruta, V., Chen, J., Lee, A. \& MacKinnon, R. } \\
& \text { Nature 423, 42-48 (2003). }
\end{aligned}
$$

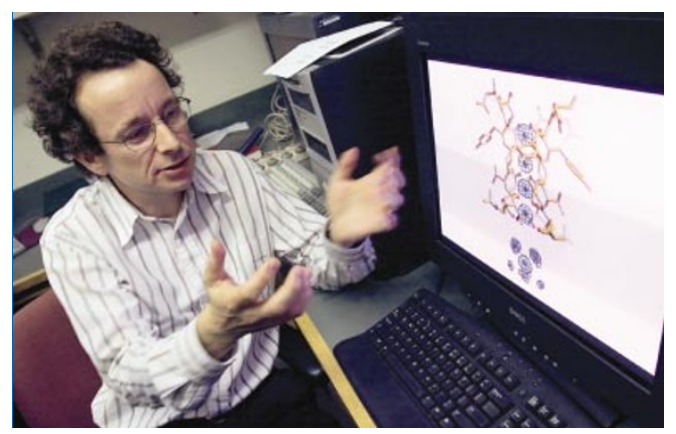

Rod MacKinnon has sparked dispute over his protein studies.
WATCHTHIS SPACE

Send in the clones

The year opened with stories of virgin birth. The Raelian cult, which maintains that the first humans were created by aliens, claimed to have produced its own baby clones. Italian fertility specialist Severino Antinori also said he had women volunteers carrying cloned fetuses. But no clone has been brought forth. The United Nations, meanwhile, debated motions to ban human cloning for reproduction and for research. But it was a similar story of build-up without birth - in the end, members agreed to put the decision off for another year.

\section{Physics heavyweights}

America's hopes of finding the Higgs boson - a particle that is involved in lending mass to other objects - in the Tevatron collider at Fermilab in Illinois were dashed this summer. Problems with the collider make it unlikely to generate enough collisions between protons and antiprotons to spy the particle. The Large Hadron Collider at CERN, near Geneva, which is scheduled to begin operating by 2007 , could offer our best chance of snaring the Higgs.

\section{Water, water everywhere}

It was the International Year of Freshwater. But the World Water Forum in Kyoto, Japan, this spring came up with little to solve the world's problems with this critical natural resource. It did not declare access to clean water a human right; neither did it demand that countries negotiate treaties on sharing rivers. The United Nations' goal of halving the proportion of people without access to safe drinking water and sanitation by 2015 seems a remote prospect.

\section{Off the menu}

The prospect of Europeans growing and eating large amounts of genetically modified (GM) food remains as remote as ever. Strict European Union laws on the need to label and trace GM crops were passed this summer, which many observers thought would ease the way for the approval of new transgenic crops. But when member states met in December to discuss approving one such crop for sale, the vote remained split. So an unofficial moratorium on new licences stays in place, at least until ministers meet next spring.

\section{Free for all}

Will the scientific literature in future be dominated by journals that do not charge their readers? That is the goal of the 'open-access' movement, which argues that the costs of publishing should be borne up front by those who fund research, rather than those who want to read about it. Open-access journals, which charge publication fees, have been proliferating over the past few years. October saw the launch of the most prominent, Public Library of Science Biology, which is competing for top biology papers with Nature, Science and Cell. 